\title{
Methanotrophic Community Detected by DNA-SIP at Bertioga's Mangrove Area, Southeast Brazil
}

Débora do Carmo Linhares, Flávia Talarico Saia, Rubens Tadeu Delgado Duarte, Cristina Rossi Nakayama, Itamar Soares de Melo, Vivian Helena Pellizari.

\begin{abstract}
Methanotrophic bacteria can use methane as sole carbon and energy source. Its importance in the environment is related to the mitigation of methane emissions from soil and water to the atmosphere. Brazilian mangroves are highly productive, have potential to methane production, and it is inferred that methanotrophic community is of great importance for this ecosystem. The scope of this study was to investigate the functional and taxonomic diversity of methanotrophic bacteria present in the anthropogenic impacted sediments from Bertioga's mangrove (SP, Brazil). Sediment sample was cultivated with methane and the microbiota actively involved in methane oxidation was identified by DNA-based stable isotope probing (DNA-SIP) using methane as a labeled substrate. After 4 days of incubation and consumption of $0.7 \mathrm{mmol}$ of methane, the most active microorganisms were related to methanotrophs Methylomonas and Methylobacter as well as to methylotrophic Methylotenera, indicating a possible association of these bacterial groups within a methane derived food chain in the Bertioga mangrove. The abundance of genera Methylomonas, able to couple methane oxidation to nitrate reduction, may indicate that under low dissolved oxygen tensions some aerobic methanotrophs could shift to intraerobic methane oxidation to avoid oxygen starvation.
\end{abstract}

Keywords: DNA-SIP, oxidation of methane, mangrove, pmoA methanotrophic bacteria, methylotrophic bacteria

\section{Acknowledgments}

We thank the research team from USP and EMBRAPA, Rosa Gamba and Dr. Armando C. F. Dias for their scientific, logistic and sampling support.

\section{Funding}

This study was funded by the São Paulo Research Foundation (FAPESP), Grant number:04/13910-6. DCL thanks the MSc scholarship financed by FAPESP, Grant number 2009/06601-0.

\section{Author information}

Affiliations

Department of Biological Oceanography, Oceanographic Institute, University of Sao Paulo, Praça do Oceanográfico, 191, 05508-120 - Butantã, São Paulo - SP, Brazil

Débora do Carmo Linhares (deboraclinhares@gmail.com), Vivian Helena Pellizari (vivianp@usp.br)

* Laboratory of Industrial Biotechnology, Institute for Technological Research of São Paulo, 05508-901, São Paulo, SP, Brazil

Débora do Carmo Linhares (dlinhares@ipt.br)

Institute of Marine Sciences, Federal University of São Paulo, Av. Dr. Carvalho de Mendonça, 144, Encruzilhada, 11070-102, Santos, SP, Brazil.

Flávia Talarico Saia (ftsaia@yahoo.com.br)

Laboratory of Molecular Ecology and Extremophiles, Department of Microbiology, Immunology and Parasitology, Federal University of Santa Catarina, 88040-900, Florianópolis, SC, Brazil

Rubens Tadeu Delgado Duarte (rubens.duarte@ufsc.br)

Institute of Environmental, Chemical and Pharmaceutical Sciences, Federal University of São Paulo, Rua São Nicolau, 210, 09913-030, Diadema, SP, Brazil.

Cristina Rossi Nakayama (crnakayama@unifesp.br)

Environmental Microbiology Lab. EMBRAPA Environment, Rodovia SP, Km 12,5.13918-110 Jaguariúna, SP, Brazil.

Itamar Soares de Melo (itamar.melo@embrapa.br)

*Recent address

\section{Corresponding author}

Correspondence to Dra Débora do Carmo Linhares, deboraclinhares@gmail.com or Dra. Vivian Helena Pellizari, vivianp@usp.br

\section{Ethics declarations}


Conflict of Interest

The authors declare no conflict of interest.

\section{ORCID number}

0000-0002-9055-9187 - Débora do Carmo Linhares

0000-0002-9199-077X - Flávia Talarico Saia

0000-0002-9939-3400 - Rubens Tadeu Delgado Duarte

0000-0001-9428-585X - Cristina Rossi Nakayama

0000-0003-2785-6725 - Itamar Soares de Melo

0000-0003-2757-6352 - Vivian Helena Pellizari

\section{Introduction}

Mangroves are tropical and subtropical ecosystems in the transition between land and marine environments. Subjected to tidal periodical flooding, mangroves present variable salinity, are muddy, oxygen poor and rich in nutrients and organic matter [1-3]. The environmental variability in mangroves sustains a highly active microbiota, which plays a central role in biogeochemical cycles, soil structure generation and decomposition, and influences the primary production and plant community dynamics [1,2].

Even though coastal marsh ecosystems are considered net sinks for carbon sequestration, spatial and temporal gradients promote a wide range of biogeochemical and anaerobic conditions, making them important sources of greenhouse gases to the atmosphere [4]. The prevalence of anaerobic conditions partnered with the high organic matter content favors methanogenesis by archaea. Methane generation is in part regulated by competition with sulfate reducing bacteria in periods of higher sulfate concentration, but methanotrophic bacteria and archaea have also a central role in reducing the total net flux of methane to the atmosphere as they are responsible for the oxidation of a significant amount of the gas produced in mangroves [5, 6]. Although anaerobic methanotrophy occurs in mangroves, coupled to sulfate, nitrate or nitrite reduction [7], the consumption of methane by aerobic bacteria is also an important process taking place in the thin oxic layer at the sediment - water interface, submerged leaf sheaths, or associated to plant roots and rhizosphere [1, 8]. Methanotrophic bacteria may also benefit from the interaction with fungi, who produce hydrophobic proteins to reduce surface tension on the hyphae, facilitating the access to hydrophobic gases such as methane [9].

Aerobic methanotrophic bacteria form a group physiologically unique and distinctive for its ability to use methane as a sole source of carbon and energy [10]. Besides their importance in the global cycle of methane and nitrogen, methanotrophic bacteria has potential application in several biotechnological processes, such as remediation of chlorinated solvents, production of polyhidroxyalcanoates (PHA), denitrification, and demethylation of methyl mercury [11], even in adverse oxygen concentrations [12].

Methanotrophic bacteria were originally grouped into Type I, II and X according to phylogeny, cellular ultrastructure, metabolic pathways, and ability to fix nitrogen [5]. As knowledge in aerobic methanotrophic diversity advanced, grouping criteria were revised. In current classification, according to phylogeny and carbon fixation pathways, methanotrophic bacteria are divided into Type I (gamma-proteobacteria using the ribulose monophosphate pathway), Type II (alpha-proteobacteria fixing carbon through the serine pathway) and Type III (Methylacidiphilae, in Phylum Verrucomicrobia, using the Calvin cycle to fix carbon derived of methane oxidation) groups. Type I methanotrophs were further divided into Types Ia (Methylococcaceae), Ib (Methylococcaceae, former Type X), Ic (Methylotehrmaceae) and Id (uncultured groups, based on pmoA sequences). Type II methanotrophs were also divided into Type IIa (Methylocystaceae) and Type IIb (Beijerinckiaceae) subgroups [13, $14]$.

Despite the importance of methanotrophic processes in regulating methane fluxes from coastal marsh ecosystems, studies of methanotrophic diversity in these environments are still scarce compared to research in 
freshwater and upland soils ecosystems. Brazilian mangroves, considered very vulnerable to damage, correspond to 7 to $8.5 \%$ of global mangrove areas and it is discontinuously distributed along the Brazilian coast [15]. Previous studies with Brazilian mangrove samples confirmed the presence of methanogenic archaea and metagenomic analysis showed sulfur metabolism prevalent in microbiomes of polluted and pristine sites [2, 16, 17]. Mesocosm experiments detected changes in bacterial communities induced by oil contamination in mangrove sediments from São Paulo State [18] and reported a preferential enrichment of the aerobic methanotroph Methylococcaeae sequences in the rhizosphere of Rhizophora mangle from Guanabara Bay mangrove, in Rio de Janeiro State [1]. Here we investigate the functional and taxonomic diversity of active methanotrophic bacteria present in oil polluted mangrove sediment samples from Bertioga (São Paulo State, Brazil), through DNA-SIP followed by the construction of 16S rRNA gene libraries, which allows studying the role of active cultured and uncultured bacteria in the oxidation of $\mathrm{CH}_{4}$

\section{Material and Methods}

\section{Sample collection and processing}

Surface sediment samples (up to $5 \mathrm{~cm}$ below sediment-water interface) were collected from a mangrove located in Bertioga, São Paulo State, in the southeast region of Brazil, in an area chronically contaminated by oil spills [2]. Sediments were sampled at $23^{\circ} 53^{\prime} 49^{\prime}$ 'S, $46^{\circ} 12^{\prime} 28^{\prime}$ 'W, from 5 points distanced by 2 to $4 \mathrm{~m}$. Sediment samples, approximately $500 \mathrm{~g}$, were collected with a sterile stainless steel spatula to the depth, sealed in sterile plastic bags and transported in a cool box at $4^{\circ} \mathrm{C}$. In the laboratory, samples were homogenized and stored at $4{ }^{\circ} \mathrm{C}$ for stable isotope probing experiment. Aliquots of $0.25 \mathrm{~g}$ of homogenized sediment were immediately stored at $-20^{\circ} \mathrm{C}$ for molecular analyses. At the moment of sampling, values of water salinity, sediment salinity, $\mathrm{pH}$, temperature, conductivity, and dissolved oxygen were $1.74 \%, 0.48 \%, 6.58,22.6^{\circ} \mathrm{C}, 8.84 \mu \mathrm{s} . \mathrm{cm}-1$ and $0.0 \mathrm{mg} . \mathrm{L}-1$, respectively.

\section{Stable isotope probing microcosms}

Five grams of homogenized sediment samples (wet weight) were incubated in $100 \mathrm{~mL}$ glass bottles filled with $40 \mathrm{~mL}$ of NMS medium (ATCC 1306), with salinity of $1.13 \%$ adjusted with synthetic reconstituted sea water (S9883, Merck, Germany), and sealed with butyl rubber stoppers and aluminum crimp caps. 13C-methane (99\% 13C, Cambridge Isotope Laboratories, Andover, USA) or ${ }_{12} \mathrm{C}$-methane (Linde, São Paulo, Brazil) was added to a final methane concentration on headspace of $8 \%(\mathrm{v} / \mathrm{v})$ under sterile conditions, using sterile $0.2 \mu \mathrm{m}$ hydrophobic PTFE syringe filters. Controls, without methane, were also included. Replicate bottles amended with ${ }_{13} \mathrm{C}$-methane or ${ }_{12} \mathrm{C}$ methane were incubated at $28^{\circ} \mathrm{C}$ in the dark at $150 \mathrm{rpm}$. Methane (99\% purity) was supplied to the microcosms whenever detected consumption was greater than $95 \%$, up to 8 additions. Before each methane addition, the bottles were flushed with sterile air to reestablish atmospheric conditions. A pair of bottles (13C-methane and ${ }_{12} \mathrm{C}$-methane) was subsequently taken for nucleic acid extraction at days 2,4 and 7, corresponding to methane consumption of 0.2 , 0.7 and $1.4 \mathrm{mmol}$, respectively. Sediment slurry was centrifuged $\left(12.000 \mathrm{x} \mathrm{g}, 40 \mathrm{~min}, 4^{\circ} \mathrm{C}\right)$ and cells in the pellet were immediately stored at $-200 \mathrm{C}$.

\section{DNA extraction and isopycnic centrifugation and fractionation}

DNA from the sediment as well as from SIP microcosms were extracted with Power Soil DNA Isolation 

methods for RNA-SIP [19] using cesium trifluoroacetate (CsTFA) gradients, without addition of formamide and

153 with a starting buoyant density (BD) of 1.61 g.mL-1. Solutions were prepared by mixing 2.0 g.mL-1 CsTFA stock solution (Amersham Biosciences) and gradient buffer described in [20]. Gradients were loaded with $10 \mu \mathrm{L}$ of DNA (500 ng) and then subject to ultracentrifugation at $64,000 \mathrm{rpm}$ and $20^{\circ} \mathrm{C}$ for $40 \mathrm{~h}$ using the same tubes, rotor and ultracentrifuge described previously [19]. Gradients were fractionated into $100 \mu \mathrm{L}$ fractions as described previously [19]. Twenty fractions were obtained through each fractionation procedure, which were numbered from 1 (heavier) to 20 (lighter). Buoyant density (BD) of fractions was determined indirectly by measuring refraction index with an AR200 digital refractometer (Reichert Inc., Depew, NY, USA) of each fraction from blank gradients run in parallel containing water instead of DNA. Sample DNA was precipitated overnight from fractions with $500 \mu \mathrm{L}$ cold isopropanol at $-20{ }^{\circ} \mathrm{C}$, followed by centrifugation $\left(14,000 \mathrm{rpm}, 30 \mathrm{~min}, 4^{\circ} \mathrm{C}\right)$. Precipitates were washed in $70 \%$ cold ethanol $(0.5 \mathrm{~mL})$ and re-eluted in $30 \mu \mathrm{L}$ elution buffer $(10 \mathrm{mM}$ Tris-HCl, $1 \mathrm{mM}$ EDTA, pH 8$)$. Total DNA was determined using the PicoGreen ${ }^{\circledR}$ ds-DNA Quantitation Kit (Invitrogen), according to the manufacturer's instructions.

\section{Denaturing Gradient Gel Electrophoresis}

Phylogenetic diversity of the bacterial communities from the sediment and from each fraction of SIP incubation with ${ }_{12} \mathrm{CH}_{4}$ and ${ }_{13} \mathrm{CH}_{4}$ at the 4 th day was analysed by denaturing gradient gel electrophoresis (DGGE). Bacterial 16S rRNA gene fragments were amplified in a PCR from $1 \mu \mathrm{L}$ extracted DNA with primers GC338F and 518R [21]. PCR program in a Mastercycler Personal-system (Eppendorf, USA) was $94^{\circ} \mathrm{C}$ for 5 min, 30 cycles $94{ }^{\circ} \mathrm{C}$ for $1 \mathrm{~min}, 55^{\circ} \mathrm{C}$ for $1 \mathrm{~min}, 72^{\circ} \mathrm{C}$ for $2 \mathrm{~min}$ and a final elongation period of 7 minutes at $72^{\circ} \mathrm{C}$. The amplified product $(7 \mu \mathrm{L})$ was analysed on an $8 \%$ polyacrylamide gel with a $45 \%-65 \%$ denaturing gradient (where the $100 \%$ denaturant contained $7 \mathrm{M}$ urea and $40 \%$ formamide) that was run for 15 hours at $60^{\circ} \mathrm{C}$ and $100 \mathrm{~V}$ in the Ingeny PhorU2 apparatus (Ingeny International, Goes, The Netherlands). Gel was silver nitrate stained [22] and DGGE profiles were visualized under white light. Comparisons of DGGE profiles were performed by cluster analysis of the banding patterns using Bionumericsтм software (Applied Maths, NV). Dendrograms were constructed by the unweighted pair group method with arithmetic mean (UPGMA) groupings with a similarity matrix based on the Pearson coefficient.

\section{Clone library and phylogenetic analysis}

In order to identify the dominant bacterial species involved in methane oxidation process, 16S rRNA clone libraries were constructed from total DNA of the sediment (GenBank accession No. MT644161-MT644186) and from a heavy and a light DNA fractions from ${ }_{13} \mathrm{CH}_{4}$ flask (fractions 12 and 15, respectively) obtained after isopycnic centrifugation (GenBank accession No. MT603661-MT603717). Clone library of pmoA genes of the sediment was also done (GenBank accession No. MT596824-MT596880).

Bacterial 16S rRNA gene fragments were PCR amplified in triplicate from $1 \mu \mathrm{L}$ of total DNA (50 ng) with primers $27 \mathrm{~F}$ [23] and $1401 \mathrm{R}$ [24]. The temperature program was $94^{\circ} \mathrm{C}$ for $5 \mathrm{~min}, 30$ cycles $94^{\circ} \mathrm{C}$ for 30 seconds, $55^{\circ} \mathrm{C}$ for 30 seconds, $72^{\circ} \mathrm{C}$ for 90 seconds and a final elongation time of 7 minutes at $72^{\circ} \mathrm{C}$. Fragments of pmoA genes were PCR amplified in triplicate from $1 \mu \mathrm{L}$ of total DNA (50 ng) with forward primer A189 [25] and reverse primer MB661 [26]. The temperature program was $94^{\circ} \mathrm{C}$ for $5 \mathrm{~min}, 30$ cycles $94^{\circ} \mathrm{C}$ for 30 seconds, $55^{\circ} \mathrm{C}$ for 30 seconds, $72^{\circ} \mathrm{C}$ for 90 seconds and a final elongation time of 7 minutes at $72^{\circ} \mathrm{C}$. Amplified $16 \mathrm{~S}$ rRNA and pmoA gene fragments were purified with Pure Link PCR Purification Kit (Invitrogen), cloned into pGEM-T-Easy 
(Promega - Madison, Wisconsin, USA) according to the manufacturer's protocol and transformed into E. coli JM109 by heat shock $\left(0^{\circ} / 42{ }^{\circ} \mathrm{C}\right.$ for 45 seconds). Cloned inserts were amplified with primers M13F and $1401 \mathrm{R}$ for $16 \mathrm{~S}$ rRNA clones, and with primers M13F and M13R for $p m o A$ clones. The temperature program for both reactions was $97^{\circ} \mathrm{C}$ for $3 \mathrm{~min}, 40$ cycles $94^{\circ} \mathrm{C}$ for 30 seconds, $60^{\circ} \mathrm{C}$ for 30 seconds, $72^{\circ} \mathrm{C}$ for 90 seconds and a final elongation time of 5 minutes at $72^{\circ} \mathrm{C}$. The amplified products were purified with Pure Link PCR Purification Kit (Invitrogen) and sequenced (MegaBACE 1000 System) with T7 primer.

Initially, all 16S rRNA sequences were checked for chimeras on the software Bellerophon [25]. Sequences considered putative chimeras or shorter than $540 \mathrm{bp}$ were excluded from further analysis. The 16S rRNA clones were aligned on Mothur v.1.42.0 [26] using the SILVA 138 reference database [27] and the alignment was checked and manually edited for position corrections using the software ARB [28]. A phylogenetic tree was constructed on ARB by the maximum likelihood method with a 1,000 bootstrap analysis. Representative reference sequences of the most closely related members were obtained from the Genbank [29] and Ribosomal Database Project - RDP [30].

A similar approach was used for the analysis of pmoA clones. The sequence alignment was performed with the Clustal W [31] within the BioEdit v7.0.9.0 package [32] and the phylogenetic tree was constructed on MEGA 7 [33] using the neighbor-joining method and a 2,000 bootstrap value.

\section{Chemical analysis}

Methane was measured by headspace analysis using a gas chromatograph (HP6850, Agilent) equipped with a flame ionization detector and a megabore column (HP-PLOT $\mathrm{Al}_{2} \mathrm{O}_{3} \mathrm{~S}, 50 \mathrm{~m} * 0.53 \mathrm{~mm} * 0.15 \mu \mathrm{m}$ ). The temperature for column chamber, inlet chamber and detector were $40 \circ \mathrm{o}$ (isothermal), $150 \circ \mathrm{C}$ and $220 \mathrm{\circ}$, respectively. High purity hydrogen was used for carrier gas, at a flow rate of $2.6 \mathrm{~mL} . \mathrm{min}-1$. The split ratio of gas sample in inlet chamber was 25:1. The flow rate at the detector was $450 \mathrm{~mL}$.min-1 for air, $45 \mathrm{~mL}$.min-1 for hydrogen and $55 \mathrm{~mL} . \mathrm{min}-1$ for nitrogen. Methane volume and concentration in microcosms' headspaces was calculated by comparing the areas of methane peaks obtained from the samples with a standard area, determined by the average of five injections of 99.95\% pure methane (standard deviation < $1 \%$ ). Clapeyron equation was used to calculate methane amounts in mmols, assuming temperature of $25^{\circ} \mathrm{C}$, atmospheric pressure $(1 \mathrm{~atm})$ and the volume corresponding to the total volume (milliliters) of methane consumed in each period.

\section{Results and Discussion}

\section{Methanotrophs from sediment of Bertioga assessed by pmoA clone library}

Methanotrophy is an important biological regulator of methane fluxes to the atmosphere. Aerobic processes were the first to be described. Anaerobic methane oxidation in hypoxic and microoxic natural and artificial environments [6,34-36] were later detected, with the use of sulfate, nitrate, nitrite and metals as electron acceptors [7], showing that methanotrophs are able to occupy a number of diverse niches where methane is present. More recently, studies have been pointing out to the ability of aerobic methanotrophs to be active in anoxic environments competing with anaerobic groups [37].

A library of pmoA gene was carried out as a preliminary attempt to access the methanotrophic diversity in the mangrove sediment. The phylogenetic tree (Figure 1) reveals that $79 \%$ of the clones grouped with the gammaproteobaterial family Methylococcaceae, and the remaining 21\% with the family Methylocystaceae, both already reported in anoxic environments [38]. Aerobic methanotrophic gammaproteobacteria are commonly detected in aquatic environments and in habitats rich in methane and at hypoxic or anaerobic conditions, indicating that there may be a niche overlap with anaerobic methanotrophs [37]. One example are species from the genus 
Methylomonas, capable of oxygen scavenging under hypoxic environments [37]. This genus was the most representative in the sediment used as inoculum, being affiliated to $21 \%$ of sequences. It has already been reported in the rhizosphere of Brazilian mangrove roots mesocosms [1]. Abundance of Methylococcaceae was also positively correlated with concentrations of hydrocarbons and negatively with dissolved oxygen in consequence of Deepwater Horizon disaster [39]. Given the fact that sequences of bacteria related to contaminated areas or able to hydrocarbon and MTBE degradation were detected in 16S rRNA libraries of the sediment (data not shown) and of SIP microcosms (Figures 4 and 5), it is possible that exposure of the microbiota to oil spills in the area of study may have contributed to the higher number of Methylococcaceae clones found.

There is also a comprehensive cluster whose nearest reference is an uncultured bacterium (FN600101.1) obtained from the rhizosphere of Oryza sativa in a rice field in Italy (unpublished). Indeed, uncultured methanotrophic groups have been observed in paddy fields in several parts of the world [40]. Moreover, 35\% of sequences grouped with uncultured organisms demonstrating the lack of characterized isolates of the group.

In the set of sequences obtained there were not representatives of other groups of methanotrophic bacteria, such as Crenothrix polyspora and those included in the Phylum Verrucomicrobia. However, their presence in the sediments cannot be excluded, since i) library coverage may not have been complete and ii) these organisms have an unusual pmoA gene, which could only be accessed through the use of modified primers and/or less restrictive conditions of PCR [41, 42].

\section{DNA-SIP microcosms}

The percentage of methane added to the microcosms was in agreement with other studies, which added 5 to $10 \%$ methane at each new supply [43-45]. In our study $0.7 \mathrm{mmol}$ of methane was consumed in 4 days of incubation which is in agreement with slurries incubated with mineral medium [43] and this strategy is quite valuable to prevent the cross-feeding, very common especially after longer periods of incubation [44, 45].

Isopycnic density gradient centrifugation of DNA extracted from cultures at 2, 4 and 7 days of incubation (T1, T2 and T3, respectively) showed an unlabeled DNA peak at BD of 1.5383 and 1.5330 (fractions 15-16) whereas ${ }_{13} \mathrm{C}$-DNA occupied fractions ranging in BD from 1.5884 to 1.5620 (fractions 9-12) (Figure2). After 2 days of incubation, with consumption of $0.2 \mathrm{mmol}$ of methane, no clear shift was obtained (Figure 2 T1). After 4 days of incubation (Figure 2 T2), DNA from fractions 11-12 was detected in the ${ }_{13} \mathrm{C}$-methane microcosm compared to the ${ }_{12} \mathrm{C}$-methane microcosm, showing incorporation of the ${ }_{13} \mathrm{C}$ into the DNA of microbiota metabolically involved in methane oxidation. At this time, consumption of $0.7 \mathrm{mmol}$ of methane was detected. After 7 days of incubation (Figure 2, T3) and $1.4 \mathrm{mmol}$ methane consumption, DNA from the heaviest fractions were also detected in the ${ }_{13} \mathrm{C}$ methane microcosm compared to the ${ }_{12} \mathrm{C}$-methane microcosm, as well as DNA from light fractions (13-14). To minimize the influence of cross-feeding on the results, only DNA samples of the T2 were chosen for further analyses.

\section{Microbial community and phylogenetic analysis}

PCR-based 16S rRNA gene DGGE analysis was carried out on the ${ }_{12} \mathrm{C}$ - and ${ }_{13} \mathrm{C}$-enriched fractions of the microcosm after 4 days of incubation (Figure 3). PCR-based 16S rRNA gene DGGE analysis of inoculum as well as of the DNA not fractionated of the microcosm were also included (Figure 3). In relation to the inoculum (lane t2), it is possible to notice that after 4 days of incubation an enrichment of microorganisms involved in the metabolism of methane can be detected, evidenced by a cluster of NF C12 and NF C13 (DNA not fractionated of the flasks incubated with ${ }_{12} \mathrm{CH}_{4}$ and ${ }_{13} \mathrm{CH}_{4}$, respectively). Bacteria fingerprints of samples incubated with ${ }_{13} \mathrm{CH}_{4}$ show that 
fractions 11-12 (T2 13C 11 and 12) formed a cluster with $88 \%$ similarity. These fractions had an increase in DNA after ${ }_{13} \mathrm{CH}_{4}$ addition, corresponding to the microorganisms that incorporated carbon from ${ }_{13} \mathrm{CH}_{4}$. Interesting to note is that light fractions of the flask incubated with ${ }_{13} \mathrm{CH}_{4}(\mathrm{~T} 2$ 13C 13-17) representing microorganisms that did not incorporated carbon from ${ }_{13} \mathrm{CH}_{4}$, formed a cluster with $78 \%$ similarity with the inoculum.

Clone libraries of the $16 \mathrm{~S}$ rRNA gene were constructed from total DNA extracted from the mangrove sediment (inoculum), and from the fractions $12(\mathrm{BD}=1.5620)$ and $15(\mathrm{BD}=1.5383)$ of the ${ }_{13} \mathrm{C}$-methane amended microcosm, corresponding to "inoculum", "heavy fraction", and "light fraction" clone libraries, respectively. Analysis of the sequences against the RDPII database revealed that there was homology with 16S rRNA gene sequences from mangroves, marine sediments and xenobiotics contaminated sites. Phylum distribution of sequences in clone libraries from sediment and light fractions were similar, with predominance of Proteobacteria, Chloroflexi, Bacteroidetes and Actinobacteria (Figure 4). These phyla were also amongst the most abundant groups in Bertioga mangrove sediments metagenomes [16], corroborating the obtained results in this work of bacterial diversity in the area of study. On the other hand, as expected, incubation of sediment with methane resulted in the enrichment of the Proteobacteria phylum, as evidenced by the distribution of sequences in the heavy fraction library.

Sequences from light fractions (Figure 5, white circles) were widely distributed into different clades and mostly associated to chemoheterotrophic bacteria. Representative genera of sulfur (Marichromatium), iron (Sideroxydans and Geobacter) and manganese (Caldimonas) oxidizing bacteria as well as sulfate reducing bacteria (Desulfobacterium) were present. Detection of sequences associated to polyaromatic hydrocarbon degradation (Alterythrobacter, Methylibium) or to oil fields (Defluvimonas) may also reflect the adaptation of the microbiota to past oil spills in the area of study. The presence of anaerobic groups is probably associated to bacteria from the inoculum carried into the culture medium and still present after the short incubation period.

Sequences from the heavy fraction (Figure 5, black circles), on the other hand were grouped mainly in clades associated to methanotrophic (Methylomonas, Methylomicrobium and Methylobacter) and methylotrophic (Methylotenera, Methyloversatilis, Methylophilus and Hyphomicrobium) groups, reflecting the associations of bacterial groups related to the methane cycle in the Bertioga mangrove sediment and in agreement with a possible methane derived microbial food chain [37]. The recovery of methylotrophic bacteria sequences in the heavy DNA fractions, in particular $\beta$-Proteobacteria, have also occurred in several studies involving the DNA-SIP technique [44-47]. Recently, cooperation between Methylobacter (Methylococcaceae) and Methylotenera versatili (Methylophilaceae) on methane oxidation was evidenced in lake Washington sediment fed with ${ }_{13} \mathrm{C}$-methane and incubated under aerobic conditions and with nitrate $(10 \mathrm{mM})$ as electron acceptor [48]. A succession of methanotrophic and methylotrophic metabolisms coupled to denitrification was also described in a membrane biofilm reactor treating perchlorate and fed with methane as sole electron donor and carbon source [49]. Initially performing anaerobic methanotrophy coupled to denitrification, the reactor biofilm was gradually dominated by Methylocysytis and at final stages, by Methylomonas cells. Under low dissolved oxygen tensions, these genera coupled methane oxidation to nitrate reduction (intraerobic methanotrophy), generating nitrite or nitrous oxide. The organic compounds derived from methanotrophy, such as methanol, were oxidized by the methylotrophic denitrifying genera Methylophilus and Methyloversatilis coupled to nitrate reduction. The authors also hypothesized that anaerobic methanotrophic microorganisms could benefit from intermediates produced by aerobic methanotrophs and both metabolisms occurred simultaneously under this methane rich anoxic environment. Similar associations may be occurring at the sediments of Bertioga mangrove. In our study, Methylomonas, Methylobacter and Methylotenera genera were dominant in the heavy fraction of DNA-SIP microcosms. NMS medium is rich in nitrate and, although incubations were carried out under aerobiosis, the concomitant presence of these groups in the 
microcosms associated to ${ }_{13} \mathrm{CH}_{4}$ consumption may indicate that under the anoxic environment of the mangrove sediment, they could shift to intraerobic methane oxidation. Another example of methylotrophic denitrifying bacterium commonly associated to methanotrophic bacteria in the heavy fraction sequences was Hyphomicrobium methylovorum. The fact that the genus Methylocystis, retrieved from sediment in pmoA clone libraries, was not detected in DNA-SIP microcosms may be related to the influence of culture conditions, probably favouring Methylomonas over Methylocystis cells.

Other clones from the heavy fraction clone library occurred at low frequency (Fig. 5). These clones might be representatives of: i) bacteria that incorporated heavy carbon through the use of secondary marked substrates such as methanol and formaldehyde or ii) sequences amplified from light DNA traces [45, 47].

\section{Conclusion}

Our work showed that aerobic bacterial community associated to methane consumption in Bertioga sediment is diverse and that they may have an important role in reducing methane emissions under aerobic or anoxic conditions. Both alpha and betaproteobacteria methanotrophs commonly associated to aquatic environments were represented in pmoA clone libraries, with predominance of the Methylococcaceae family, in special Methylomonas and Methylobacter genera. Methylocystaceae family was also represented by Methylocystis sequences and a clade of sequences related to an uncultured clone sequence also indicate that other methanotrophic groups are yet to be identified.

DNA-SIP technique, followed by analysus of 16S rRNA gene, was a suitable tool to detect active microorganisms related to methane oxidation, using microcosms with NMS medium containing nitrate and amended with methane as sole source of carbon and energy. Sequences from light fractions were broadly distributed into clades of chemoheterotrophic bacteria, including groups associated to hydrocarbon degradation or to oil fields, as well as genera related to sulfur, iron and manganese oxidizing and sulfate reducing metabolisms. Microbial groups involved in ${ }_{13} \mathrm{CH}_{4}$ consumption were mostly methanotrophic (Methylomonas, Methylomicrobium and Methylobacter) and methylotrophic (Methylotenera, Methyloversatilis, Methylophilus, and Hyphomicrobium) bacteria. Their co-occurrence in DNA-SIP microcosms suggests that a microbial methane food chain may be established in Bertioga sediments and it is possibly able to shift from aerobic methanotrophy to methane oxidation coupled to nitrate reduction when oxygen concentrations are low.

\section{Compliance with Ethical Standards}

349 The authors declared that they have no conflicts of interest to this work. We declare that we do not have any commercial or associative interest that represents a conflict of interest in connection with the work submitted.

\section{References}

1. Gomes NCM, Cleary DFR, Pinto FN, et al (2010) Taking root: Enduring effect of rhizosphere bacterial colonization in mangroves. PLoS One 5:1-10. https://doi.org/10.1371/journal.pone.0014065

2. Dias ACF, Dini-Andreote F, Taketani RG, et al (2011) Archaeal communities in the sediments of three contrasting mangroves. J Soils Sediments 11:1466-1476. https://doi.org/10.1007/s11368-011-0423-7

3. Pupin B, Nahas E (2014) Microbial populations and activities of mangrove, restinga and Atlantic forest soils from Cardoso Island, Brazil. J Appl Microbiol 116:851-864. https://doi.org/10.1111/jam.12413 
Mangrove (Kandelia obovata) Soils Under Different Frequency of Tides. Microb Ecol 75:761-770. https://doi.org/10.1007/s00248-017-1080-1

5. Hanson RS, Hanson TE (1996) Methanotrophic bacteria. Microbiol Rev 60:439-71

6. Rastogi G, Ranade DR, Yeole TY, et al (2009) Novel methanotroph diversity evidenced by molecular characterization of particulate methane monooxygenase A (pmoA) genes in a biogas reactor. Microbiol Res 164:536-544. https://doi.org/10.1016/j.micres.2007.05.004

7. Dai Z, Trettin CC, Frolking S, Birdsey RA (2018) Mangrove carbon assessment tool: Model development and sensitivity analysis. Estuar Coast Shelf Sci 208:23-35. https://doi.org/10.1016/j.ecss.2018.04.035

8. Chowdhury TR, Dick RP (2013) Ecology of aerobic methanotrophs in controlling methane fluxes from wetlands. Appl Soil Ecol 65:8-22. https://doi.org/10.1016/j.apsoil.2012.12.014

9. Oliver JP, Schilling JS (2018) Harnessing fungi to mitigate CH4 in natural and engineered systems. Appl Microbiol Biotechnol 102:7365-7375. https://doi.org/10.1007/s00253-018-9203-2

10. Wise MG, McArthur JV, Shimkets LJ (1999) Methanotroph diversity in landfill soil: Isolation of novel type I and type II methanotrophs whose presence was suggested by culture-independent 16S ribosomal DNA analysis. Appl Environ Microbiol 65:4887-4897. https://doi.org/10.1128/aem.65.11.4887-4897.1999

11. Kwon M, Ho A, Yoon S (2019) Novel approaches and reasons to isolate methanotrophic bacteria with biotechnological potentials: recent achievements and perspectives. Appl Microbiol Biotechnol 103:1-8. https://doi.org/10.1007/s00253-018-9435-1

12. Costa RB, Okada DY, Martins TH, Foresti E (2018) Aerobic methanotrophs grew under anoxic conditions and supported a diverse heterotrophic bacterial community. Environ Eng Sci 35:804-814. https://doi.org/10.1089/ees.2017.0346

13. Knief C (2019) Diversity of Methane Cycling Microorganisms in Soils and Their Relation to Oxygen

14. Op den Camp HJM, Islam T, Stott MB, et al (2009) Environmental, genomic and taxonomic perspectives on methanotrophic Verrucomicrobia. Environ Microbiol Rep 1:293-306. https://doi.org/10.1111/j.17582229.2009.00022.x

15. Schaeffer-Novelli Y, Soriano-Sierra EJ, Câmara Do Vale C, et al (2016) Climate changes in mangrove forests and salt marshes. BRAZILIAN J Oceanogr 64:37-52. https://doi.org/10.1590/S1679$875920160919064 \mathrm{sp} 2$

16. Andreote FD, Jiménez DJ, Chaves D, et al (2012) The microbiome of Brazilian mangrove sediments as revealed by metagenomics. PLoS One 7:. https://doi.org/10.1371/journal.pone.0038600

17. Cotta SR, Cadete LL, van Elsas JD, et al (2019) Exploring bacterial functionality in mangrove sediments and its capability to overcome anthropogenic activity. Mar Pollut Bull 141:586-594. https://doi.org/10.1016/j.marpolbul.2019.03.001

18. Taketani RG, Franco NO, Rosado AS, van Elsas JD (2010) Microbial community response to a simulated hydrocarbon spill in mangrove sediments. J Microbiol 48:7-15. https://doi.org/10.1007/s12275-009-0147-1

19. Whiteley AS, Thomson B, Lueders T, Manefield M (2007) RNA stable-isotope probing. Nat Protoc 2:838844. https://doi.org/10.1038/nprot.2007.115

20. Neufeld JD, Vohra J, Dumont MG, et al (2007) PROTOCOL DNA stable-isotope probing. Analysis 2:860866. https://doi.org/10.1038/nprot.2007.109

21. Øvreås L, Forney L, Daae FL, Torsvik V (1997) Distribution of bacterioplankton in meromictic lake Saelenvannet, as determined by denaturing gradient gel electrophoresis of PCR-amplified gene fragments coding for 16S rRNA. Appl Environ Microbiol 63:3367-3373. https://doi.org/10.1128/aem.63.9.33673373.1997

22. Macek M, Mercier B, Macková A, et al (1997) Sensitivity of the denaturing gradient gel electrophoresis technique in detection of known mutations and novel Asian mutations in the CFTR gene. Hum Mutat 9:136147. https://doi.org/10.1002/(SICI)1098-1004(1997)9:2<136::AID-HUMU6>3.0.CO;2-7 
24. Nübel U, Engelen B, Felsre A, et al (1996) Sequence heterogeneities of genes encoding 16S rRNAs in Paenibacillus polymyxa detected by temperature gradient gel electrophoresis. J Bacteriol 178:5636-5643. https://doi.org/10.1128/jb.178.19.5636-5643.1996

25. Huber T, Faulkner G, Hugenholtz P (2004) Bellerophon: A program to detect chimeric sequences in multiple sequence alignments. Bioinformatics 20:2317-2319. https://doi.org/10.1093/bioinformatics/bth226

26. Schloss PD, Westcott SL, Ryabin T, et al (2009) Introducing mothur: Open-source, platform-independent, community-supported software for describing and comparing microbial communities. Appl Environ Microbiol 75:7537-7541. https://doi.org/10.1128/AEM.01541-09

27. Pruesse E, Quast C, Knittel K, et al (2007) E. Pruesse - SILVA: a comprehensive online resource for quality checked and aligned ribosomal RNA sequence data compatible with ARB. In: Nucleic Acids Res. https://kopernio.com/viewer?doi=10.1093/nar/gkm864\&route=6. Accessed 21 Jun 2020

28. Ludwig W, Strunk O, Westram R, et al (2004) ARB: A software environment for sequence data. Nucleic Acids Res 32:1363-1371. https://doi.org/10.1093/nar/gkh293

29. Benson DA, Karsch-Mizrachi I, Lipman DJ, et al (2005) GenBank. Nucleic Acids Res 33:34-38. https://doi.org/10.1093/nar/gki063

30. Cole JR, Wang Q, Cardenas E, et al (2009) The Ribosomal Database Project: Improved alignments and new tools for rRNA analysis. Nucleic Acids Res 37:141-145. https://doi.org/10.1093/nar/gkn879

31. Thompson JD, Gibson TJ, Plewniak F, et al (1997) The CLUSTAL X windows interface: Flexible strategies for multiple sequence alignment aided by quality analysis tools. Nucleic Acids Res 25:4876-4882. https://doi.org/10.1093/nar/25.24.4876

32. Hall TA (1999) The green synthesis of ultrafine palladium-phosphorus alloyed nanoparticles anchored on polydopamine functionalized graphene used as an excellent electrocatalyst for ethanol oxidation. Nucleic Acids Symp. 41:95-98

33. Kumar S, Stecher G, Tamura K (2016) MEGA7: Molecular Evolutionary Genetics Analysis Version 7.0 for Bigger Datasets. Mol Biol Evol 33:1870-1874. https://doi.org/10.1093/molbev/msw054

34. Henckel T, Jäckel U, Schnell S, Conrad R (2000) Molecular analyses of novel methanotrophic communities in forest soil that oxidize atmospheric methane. Appl Environ Microbiol 66:1801-1808. https://doi.org/10.1128/AEM.66.5.1801-1808.2000

35. Ettwig KF, Butler MK, Le Paslier D, et al (2010) Nitrite-driven anaerobic methane oxidation by oxygenic bacteria. Nature 464:543-548. https://doi.org/10.1038/nature08883

36. Luesken FA, Van Alen TA, Van Der Biezen E, et al (2011) Diversity and enrichment of nitrite-dependent anaerobic methane oxidizing bacteria from wastewater sludge. Appl Microbiol Biotechnol 92:845-854. https://doi.org/10.1007/s00253-011-3361-9

37. Lee EY (2019) Methanotrophs: microbiology fundamentals and biotechnological applications

38. Chistoserdova L (2015) Methylotrophs in natural habitats: current insights through metagenomics. Appl Microbiol Biotechnol 99:5763-5779. https://doi.org/10.1007/s00253-015-6713-z

39. Rivers AR, Sharma S, Tringe SG, et al (2013) Transcriptional response of bathypelagic marine bacterioplankton to the Deepwater Horizon oil spill. ISME J 7:2315-2329. https://doi.org/10.1038/ismej.2013.129

40. Lüke C, Krause S, Cavigiolo S, et al (2010) Biogeography of wetland rice methanotrophs. Environ Microbiol 12:862-872. https://doi.org/10.1111/j.1462-2920.2009.02131.x

41. Pol A, Heijmans K, Harhangi HR, et al (2007) Methanotrophy below pH 1 by a new Verrucomicrobia species. Nature 450:874-878. https://doi.org/10.1038/nature06222

42. Stoecker K, Bendinger B, Schöning B, et al (2006) Cohn's Crenothrix is a filamentous methane oxidizer with an unusual methane monooxygenase. Proc Natl Acad Sci U S A 103:2363-2367. https://doi.org/10.1073/pnas.0506361103

43. Cébron A, Bodrossy L, Stralis-Pavese N, et al (2007) Nutrient amendments in soil DNA stable isotope 
probing experiments reduce the observed methanotroph diversity. Appl Environ Microbiol 73:798-807. https://doi.org/10.1128/AEM.01491-06

44. Cébron A, Bodrossy L, Chen Y, et al (2007) Identity of active methanotrophs in landfill cover soil as revealed by DNA-stable isotope probing. FEMS Microbiol Ecol 62:12-23. https://doi.org/10.1111/j.15746941.2007.00368.x

45. Mcdonald IR, Radajewski S, Murrell JC (2005) Stable isotope probing of nucleic acids in methanotrophs and methylotrophs : A review. Org Geochem 36:779-787. https://doi.org/10.1016/j.orggeochem.2005.01.005

46. Morris SA, Radajewski S, Willison TW, Murrell JC (2002) Identification of the functionally active methanotroph population in a peat soil microcosm by stable-isotope probing. Appl Environ Microbiol 68:1446-1453. https://doi.org/10.1128/AEM.68.3.1446-1453.2002

47. Radajewski S, Webster G, Reay DS, et al (2002) Identification of active methylotroph populations in an acidic forest soil by stable-isotope probing. Microbiology 148:2331-2342. https://doi.org/10.1099/00221287-148-8-2331

48. Beck DAC, Kalyuzhnaya MG, Malfatti S, et al (2013) A metagenomic insight into freshwater methaneutilizing communities and evidence for cooperation between the Methylococcaceae and the Methylophilaceae. PeerJ 2013:1-23. https://doi.org/10.7717/peerj.23

49. Chen R, Luo YH, Chen JX, et al (2016) Evolution of the microbial community of the biofilm in a methanebased membrane biofilm reactor reducing multiple electron acceptors. Environ Sci Pollut Res 23:95409548. https://doi.org/10.1007/s11356-016-6146-y 
bioRxiv preprint doi: https://doi.org/10.1101/2020.08.20.255125; this version posted August 21,2020 . The copyright holder for this preprint (which was not certified by peer review) is the author/funder, who has granted bioRxiv a license to display the preprint in perpetuity. It is made available under aCC-BY-NC-ND 4.0 International license.

\section{FIGURES}

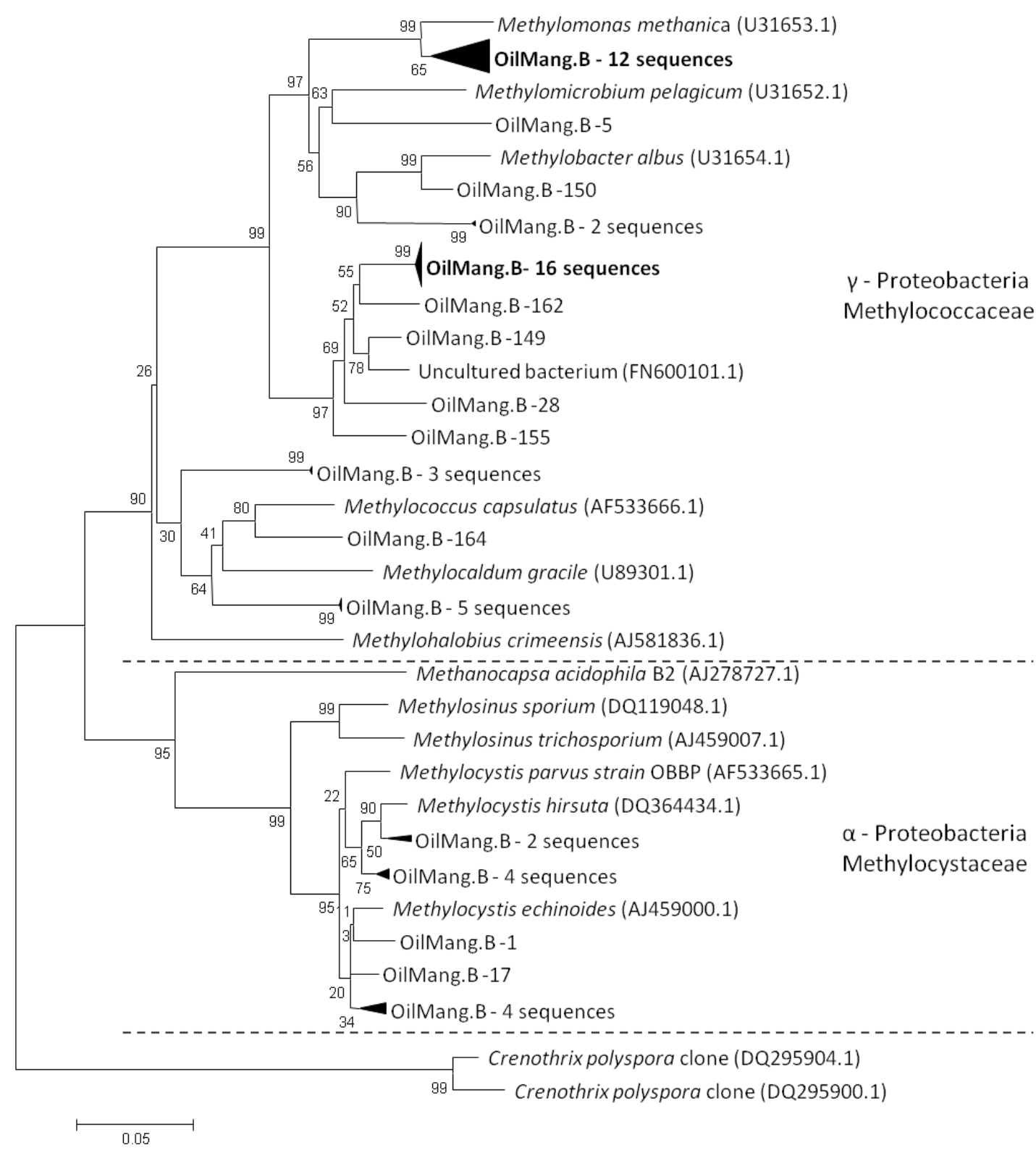

Fig. 1 Phylogenetic neighbour-joining tree of pmoA gene sequences from clone library constructed from sediment of Bertioga's mangrove, at oil impacted site (OilMang.B). Reference strains and clones sequences were taken from GenBank and are named by their accession numbers. Bootstrap values derived from 2000 replicates are shown and were obtained using a distance matrix program neighbour-joining method within MEGA 7.0. The bar represents $5 \%$ sequence divergence. 

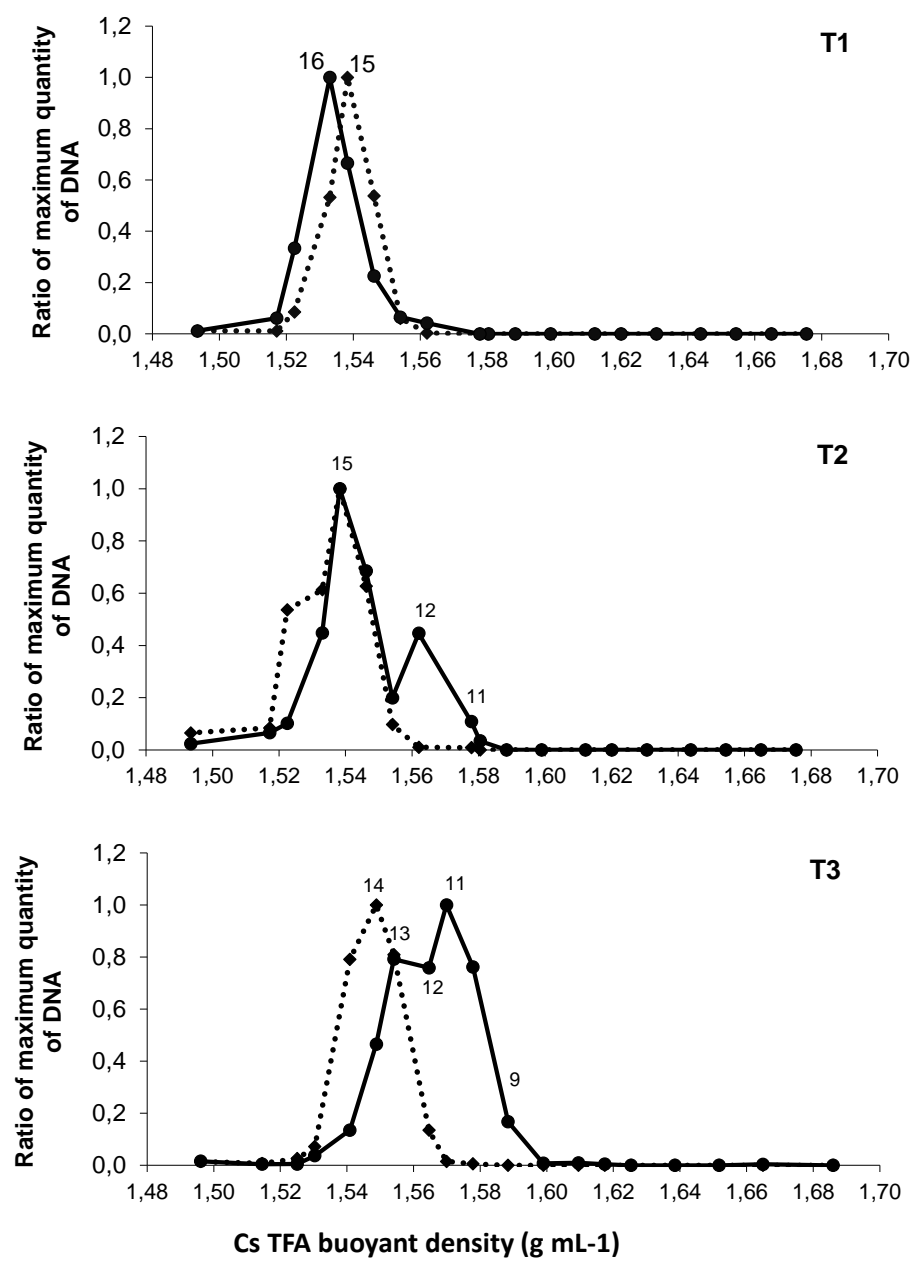

Fig. 2 Quantitative distribution of DNA across the entire range of buoyant density (BD) of the DNA-SIP fractions from sediment microcosms incubated with 12CH4 (12C-DNA dotted line), and 13CH4 (13C-DNA solid line) for 2, 4 and 7 days of incubation (T1, T2 and T3, respectively). The numbers in the plot represent the fractions of prominence.
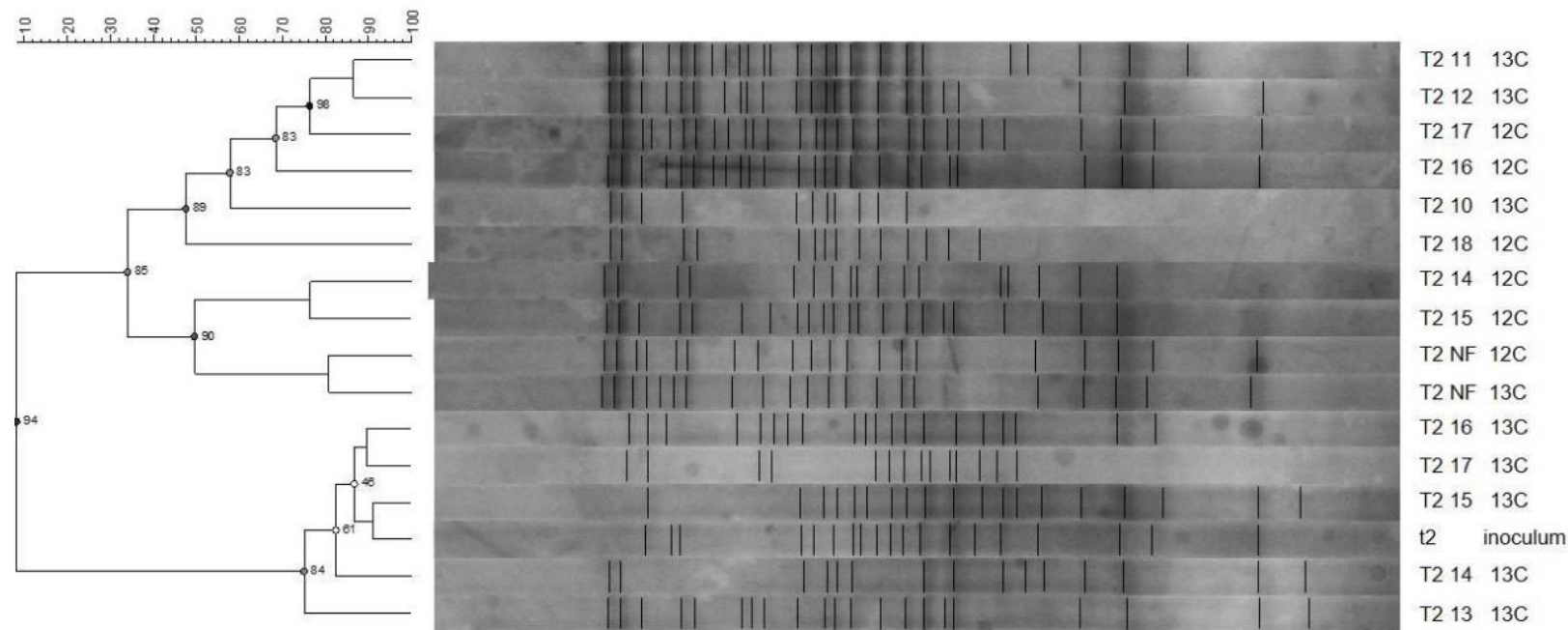

Fig. 3 Cluster analysis of16S rDNA DGGE fingerprint of fractionated DNA recovered from $12 \mathrm{CH} 4$ and $13 \mathrm{CH} 4$ microcosms from mangrove samples (Bertioga, São Paulo State, Brazil), at the 4th day of incubation (T2). The denaturing gradient ranged from $45 \%$ to $65 \%$. Cluster analysis was performed with the Bionumerics software (Applied Maths, NV), using UPGMA method and Pearson coefficient. Cophenetic correlation values are shown in the nodes. Labels in each lane indicate: incubation time (T2 = 4 days); number of recovered fractions after SIP-DNA experiment and isopycnic centrifugation; enrichment carbon source $(12 \mathrm{C}=12 \mathrm{CH} 4$ or $13 \mathrm{C}=13 \mathrm{CH} 4)$. t2, inoculum; NF, non-fractionated. 
bioRxiv preprint doi: https://doi.org/10.1101/2020.08.20.255125; this version posted August 21,2020 . The copyright holder for this preprint (which was not certified by peer review) is the author/funder, who has granted bioRxiv a license to display the preprint in perpetuity. It is made available under aCC-BY-NC-ND 4.0 International license.

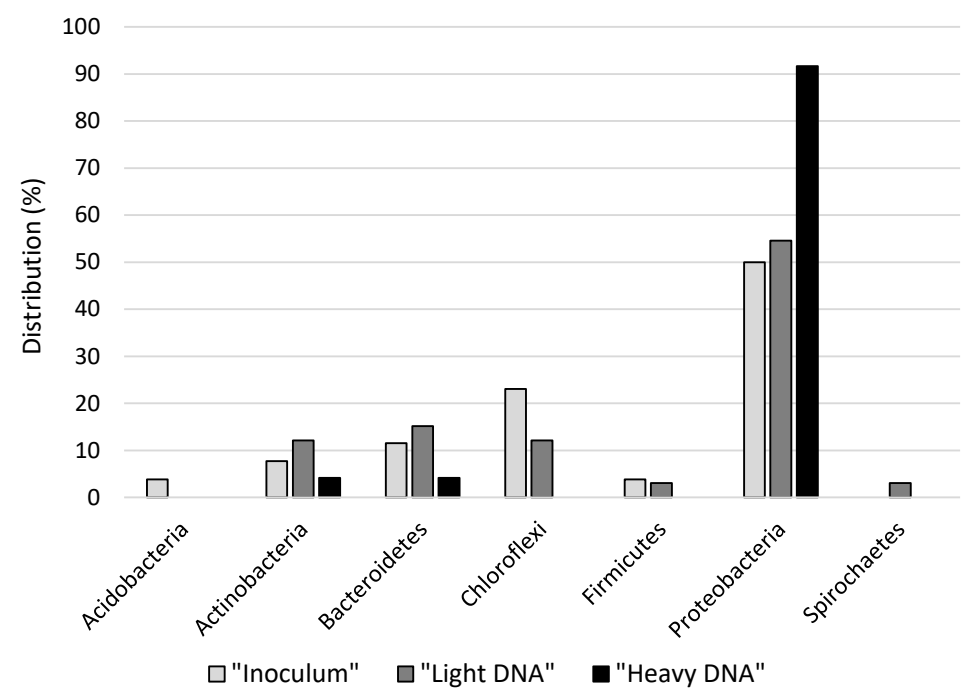

Fig. 4 Phylum distribution detected by 16S RNA clone library from mangrove sediment (inoculum) and from light and heavy fractions derived from DNA-SIP experiment of microcosms enriched with methane $\left({ }_{13} \mathrm{CH}_{4}\right)$. 
bioRxiv preprint doi: https://doi.org/10.1101/2020.08.20.255125; this version posted August 21, 2020. The copyright holder for this preprint (which was not certified by peer review) is the author/funder, who has granted bioRxiv a license to display the preprint in perpetuity. It is made available under aCC-BY-NC-ND 4.0 International license.

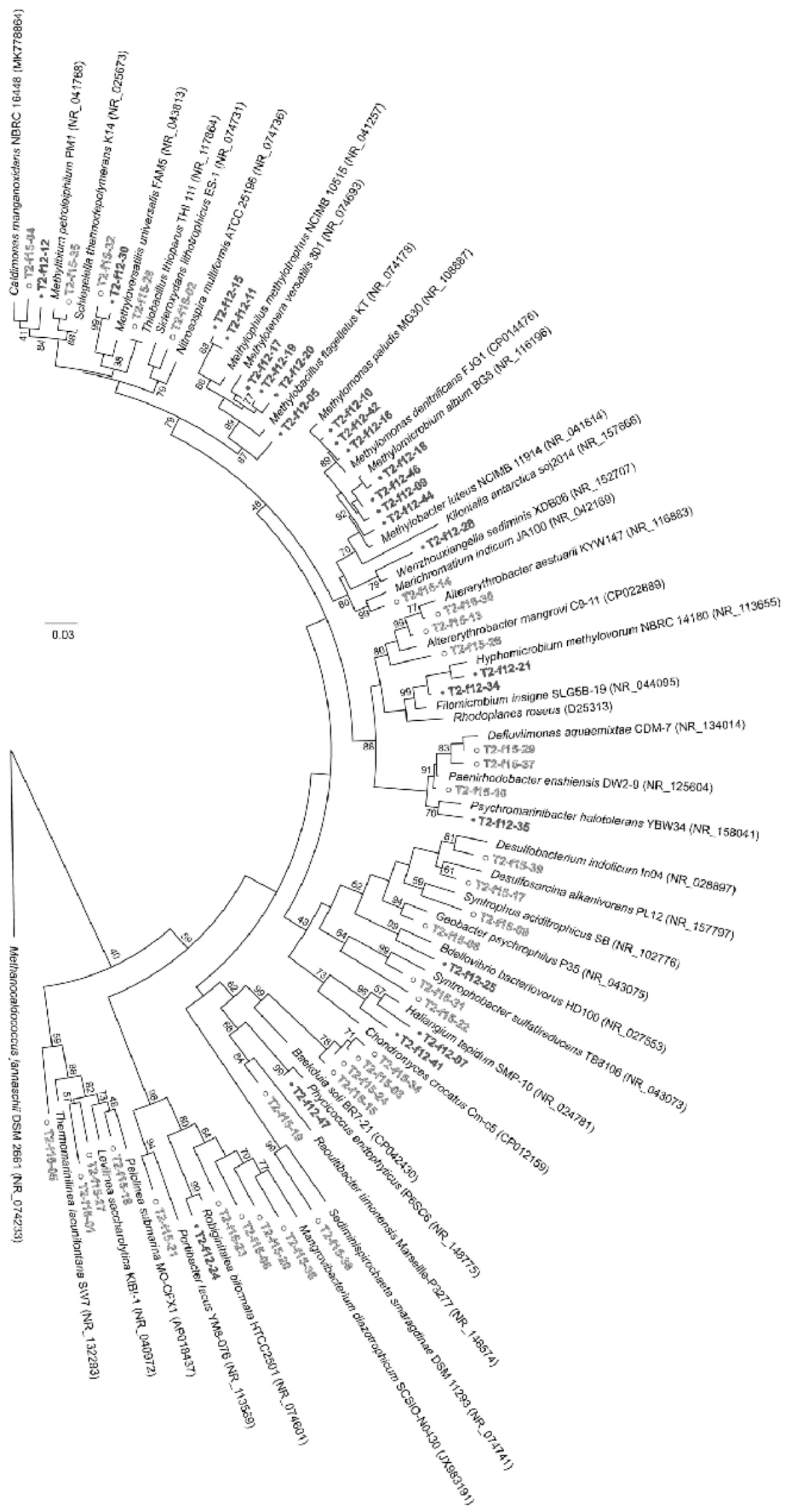

Fig. 5 Phylogenetic tree of 16S rRNA gene, obtained from DNA of light (white circles) and heavy (black circles) fractions recovered from DNA-SIP experiment of mangrove sediment microcosms incubated with 13CH4. The maximum likelihood method with a 1,000 bootstrap analysis was used and representative reference sequences of the most closely related members were obtained from the Genbank and RDP. 